\title{
The prefrontal cortex: Projection area of the thalamic mediodorsal nucleus?
}

\author{
HANS J. MARKOWITSCH and MONIKA PRITZEL \\ University of Konstanz, P.O. Box 7733, D-7750 Konstanz, Federal Republic of Germany
}

\begin{abstract}
The historical bases of the definitions of the prefrontal cortex are reviewed (cytoarchitecture, electrical unexcitability, afferents from the mediodorsal thalamic nucleus). Evidence is presented that the widely accepted proposal of Rose and Woolsey (1948) to name all cortex prefrontal that is reached by afferents from the mediodorsal nucleus is questionable for three reasons: the diversity of cortical fields reached by the mediodorsal nucleus, the overlapping of thalamic projections, and the possibility of a column- or band-like thalamocortical organization. An alternative approach to a definition of the prefrontal cortex is suggested.
\end{abstract}

At the turn of the century, the frontal lobes were divided into two regions on the basis of morphological and functional criteria. Functionally, a region related to movements was distinguished from a more rostrally situated region that was unrelated to movements (Ferrier, 1875; Feuchtwanger, 1923; Franz, 1902; Hines, 1929; Hitzig, 1884; Walker, 1957; Wundt, 1908). Anatomically, Brodmann (1909, 1912) discriminated the agranular area (i.e., cortex without granular cell layer IV), named "regio praecentralis," from the more rostrally situated granular area (i.e., cortex with granular cell layer IV), called "regio frontalis."

To denote those areas situated rostral to the electrically excitable motor, premotor and frontal eye fields, the term "prefrontal cortex" was coined by Ferrier in 1886 (cited in Tobias, 1975) and applied to human (e.g., Bolton, 1903; Flechsig, 1896) and nonhuman primates (e.g., Horsley \& Schäfer, 1888). For nonprimates, the use of this term was retarded. Reasons for this may be sought in the relatively small overall size of the frontal lobes of nonprimate compared to primate brains, in the long and impassioned disputes for or against motor vs. "higher" functions of the frontal lobes of dog and cat (reviewed and discussed in Bianchi, 1895), and particularly in the diminutive size of the "frontal granular cortex" in nonprimate species (Ariens-Kappers, Huber, \& Crosby, 1936; Brodmann, 1909, 1912).

Only the suggestion of Rose and Woolsey (1948a), that the extent of the prefrontal cortex ("orbitofrontal cortex" in their terminology) "be defined as the projection area of the mediodorsal nucleus" (p. 232) of the thalamus, brought a new impetus to include nonprimates in research on the prefrontal cortex (for reviews, see Markowitsch \& Pritzel, 1976, 1977).

The connections of the mediodorsal nucleus with the frontal cortex were known as early as the end of the 19th century (von Monakow, 1895), and were investigated further in numerous studies using primates (Clark \& Boggon, 1935; Crouch, 1940; Freeman \& Watts, 1947; Mettler, 1947; Meyer, Beck \& McLardy, 1947; Minkowski, 1923; Rutishauser, 1899; Sachs, 1909; Walker, 1940) and in a few studies employing cats (Clark \& Boggon, 1933; Sachs, 1909; Waller, 1940; Waller \& Barris, 1937) and rats (Clark, 1932; Clark \& Boggon, 1933; Krieg, 1947; Lashley, 1941). Warren, Warren, and Akert (1962) reviewed earlier behavioral "frontal cortex" research in mammalia of different species. The relevance of thalamocortical connections for interspecies comparisons of the functions of the prefrontal cortex was, however, recognized only relatively lately.

Since the time of Lashley (1929), a preferred laboratory animal for research in physiological psychology has been the rat, but the mediodorsal afferents to the cortex of this species were investigated neither by Akert (1964) nor by Rose and Woolsey (1948a). Only a few nonprimate studies, mainly with prefrontally lesioned cats and dogs, appeared until the end of the last decade (Brutkowski, 1965; Markowitsch \& Pritzel, 1976, 1977; Warren \& Akert, 1964). The statement of Akert (1964, p. 380) that Rose and Woolsey (1948a) had investigated the rat, is wrong; he probably meant "rabbit."

Behavioral investigators who used rats regarded the cortex of the frontal pole as prefrontal, probably mainly on topological grounds (e.g., Lukaszewska, 1971), until Leonard (1969) showed, in an anterograde degeneration study, that the rat's mediodorsal nucleus projects to two separate cortical fields, neither of which extends to the frontal pole. Both Leonard (1969) and Rose and Woolsey (1948a) pointed out some dangers associated with the definition of the prefrontal cortex as being the projection area of the mediodorsal nucleus. Rose and Woolsey cautiously termed their cortical projection fields "orbitofrontal," 
to avoid a direct comparison with the "granular frontal formations of primates" (p. 211). Akert (1964), however, later suggested that the mediodorsal projection fields of nonprimates could be called granular for the following reasons: "Since this cortex has six inconspicuous layers and since it is narrower in comparison with the agranular cortex, we consider it granular despite the paucity of granular cells" (p. 378). Leonard stressed that the early definition of the prefrontal cortex as "silent" and nonmotor disagrees with a thalamocortical definition, because in the latter the nonsilent frontal eye field has to be termed prefrontal as well.

In spite of these inconsistencies, the definition of the prefrontal cortex as the projection area of the mediodorsal nucleus has been favored to the neglect of the definitions based on cytoarchitecture or on motor vs. nonmotor functions. Anatomical research of recent years has defined or redefined the prefrontal cortex on the basis of its mediodorsal thalamic connections. This has been done for the rhesus monkey (Akert, 1964; Pribram, Chow, \& Semmes, 1953; Tobias, 1975), squirrel monkey (Akert, 1964), bush baby (Skeen \& Masterton, 1976), tree shrew (Skeen, 1974), dog (Narkiewicz \& Brutkowski, 1967; Akert, 1964), cat (Akert, 1964; Markowitsch, Pritzel, \& Divac, 1978), opossum (Tobias \& Ebner, 1973), rabbit (Benjamin, Jackson, \& Golden, 1978), and rat (Beckstead, 1976; Divac, Kosmal, Lindvall, \& Björklund, 1976; Krettek \& Price, 1977; Leonard, 1969, 1972).

Likewise, this definition of the prefrontal cortex seems to have been accepted nearly exclusively in the behavioral research of the last decade. Studies on monkeys, cats, and rats are reviewed in Markowitsch and Pritzel $(1976,1977)$. Studies of other species have been done by Passingham (1978), Shipley and Kolb (1977), and Skeen and Masterton (1976).

We will now show, however, that the reliance of recent anatomical and behavioral research on this definition of the prefrontal cortex is questionable for three major reasons. First, anatomical research in the rat, cat, and rhesus monkey has made it apparent that the mediodorsal nucleus projects to rather wide and divergent cortical fields, some of which lie outside the traditional borders of the prefrontal cortex (e.g., Ariens-Kappers et al., 1936; Brodmann, 1909, 1912; Stanley \& Jaynes, 1949). Second, those cortical areas receiving a direct input from the mediodorsal thalamic nucleus often also receive further inputs from other thalamic nuclei; these overlapping projections violate Rose and Woolsey's (1948a) basic assumption that "although it is possible that some frontal fields are altogether athalamic, it appears certain that no other thalamic projections except those from the mediodorsal element reach the frontal fields" (p. 210). Third, recent anatomical evidence
(Berson \& Graybiel, 1978; Kievit \& Kuypers, 1975, 1977) challenges the view that each of the specific thalamic nuclei projects to its specific cortical field(s) (Mountcastle \& Poggio, 1974), and suggests, rather, that vertically oriented thalamic columns, which may cross nuclear borders, are related to vertically oriented cortical bands, which may also cross the borders of the traditionally established areas.

\section{CORTICAL PROJECTIONS OF THE MEDIODORSAL NUCLEUS}

Only results of recent studies using predominantly either the retrograde horseradish peroxidase method (Cowan, 1975; Heimer \& Lohman, 1975; Kristensson \& Olson, 1971; LaVail \& LaVail, 1972) or the anterograde autoradiographic tracing technique (Cowan, 1975; Heimer \& Lohman, 1975; Lasek, Joseph, \& Whitlock, 1968) will be considered.

\section{Rat}

In the rat, Leonard (1969) for the first time provided detailed evidence that the prefrontal cortex of a species is not situated topologically "prefrontal." Instead, she found that the mediodorsal nucleus projects both to the medial wall of the hemisphere rostral to the genu of the corpus callosum and to the region above the rhinal sulcus on the lateral wall of the hemisphere.

The area on the medial wall had been termed cingulate cortex in earlier studies (Krieg, 1946), while the area on the lateral wall had been considered an insular region (Brodmann, 1909, 1912; M. Rose, 1929; Stephan, 1975). Later studies by Divac et al. (1976), Domesick (1972), Krettek and Price (1977) and Leonard (1972) confirmed Leonard's original results in essence.

\section{Cat}

Compared to the anatomical research in the rat, little has been done in the cat since the appearance of Akert's (1964; Warren et al., 1962) and Rose and Woolsey's (1948a) studies. Using the horseradish peroxidase method, Markowitsch et al. (1978) redefined the extent of the cat's prefrontal cortex. Contrary to the earlier studies, their results also point to the existence of two differentially localized cortical areas that receive projections from the mediodorsal nucleus. Aside from the traditionally known area around the frontal pole, a further region, occupying parts of the insular cortex above the rhinal sulcus, was detected. Functionally, this insular region seems to belong among the polysensory integration areas of the cat's cortex (Avancini, Mancia, \& Pelliccioli, 1969; Benevento \& Loe, 1975; Buser \& Bignall, 1967; Stephan, 1975). 


\section{Monkey}

Tobias (1975) in the rhesus monkey found "that all of the cerebral neocortex, anterior to 'motor' areas, receives input from MD [mediodorsal nucleus]" (p. 205). He especially established that not only the dorsolateral and orbitofrontal areas of Akert (1964, Figure 18.18), but also parts of the cingulate cortex belong to the prefrontal cortex as defined by Rose and Woolsey. Akert (1964, Figure 18.4) did not detect retrograde degeneration in the mediodorsal thalamic nucleus after ablations of the cortex in the medial wall and had therefore suggested that this cortex might be athalamic and "may represent 'association' cortex in the classical sense" (p. 381).

While mediodorsal cells projected, in Tobias' study at least, only to regions around the frontal pole, experimenters have more recently detected mediodorsal projections to the caudal part of the precentral gyrus corresponding to the regio praecentralis of Brodmann (Kievit \& Kuypers, 1977), to the parietal cortex above the sylvian fissure (Mesulam, van Hoesen, Pandya, \& Geschwind, 1977, p. 404; Stanton, Cruce, Goldberg, \& Robinson, 1977a, $1977 \mathrm{~b}$, Figure 3), and to the temporal cortex below the sylvian fissure (Trojanowski, 1977; Trojanowski \& Jacobson, 1976). Projections above the sylvian fissure definitely extended to the lateral convexity of the hemisphere, and projections below the sylvian fissure probably did. These results suggest also that, in the monkey, portions of the insular region, or at least portions of the region around the sylvian fissurewhich topographically is situated similar to the (pseudo-)sylvian fissure of the cat's cortex, where the second mediodorsal projection field is centered-are part of the cortical projection areas of the mediodorsal nucleus. Locke (1967) had earlier reported mediodorsal afferents to the monkey's insular region.

\section{Other Species}

A dual organization of mediodorsal afferents to the cortex has also been observed in the tree shrew (Skeen, 1974). In this species, one area "is situated on the lateral convexity of the frontal pole" and the other "lies along the anterior extent of the rhinal fissure" (Skeen, 1974).

In the rabbit and opossum, the mediodorsal projection fields seem to be united. In the opossum, afferents end "on the dorsolateral convexity of the hemisphere just rostral to the orbital sulcus" (Tobias \& Ebner, 1973, p. 79), and seem therefore to be rather limited compared to those of other species. In the rabbit, on the other hand, the projection field occupies "the entire wall rostral to a midcorpus callosal level, wrap[s] around the frontal pole onto the lateral convexity and tail[s] off caudally on the dorsal bank of the rhinal sulcus" (Benjamin et al., 1978, p. 251).

\section{THALAMIC PROJECTIONS TO THE PREFRONTAL FIELDS}

As already noted, Rose and Woolsey repeatedly postulated one-to-one relations between a thalamic nucleus and its cortical "essential projection area" (Rose \& Woolsey, 1948a, 1948b, 1949). They stated that an overlapping projection of two thalamic nuclei might occur only for the fringes of adjacent cortical areas (Rose \& Woolsey, 1948b).

This requirement seems to become the exception instead of the rule in horseradish peroxidase studies of the prefrontal cortex. Thus, in the rat, the "medioventral, parataenial, interanteromedial, posterolateral and intralaminar-midline" nuclei project to the prefrontal cortex (Divac et al., 1976). These strong overlapping projections were also noted by Beckstead (1976; cf. especially his Table 1, giving the distributions of labeled thalamic neurons after anterior cortical injections).

In the cat, Markowitsch, Pritzel, and Divac (unpublished observations) noted after cortical injections which labeled mediodorsal cells, labeled cells also in the nuclei ventralis anterior, ventralis lateralis, ventralis medialis, anteromedialis, centralis lateralis, centrum medianum, centralis medialis, parataenialis, and submedius. Similarly, Niimi, Niimi, and Okada (1978) observed that "injections in the anterior limbic region adjacent to the granular frontal cortex led to labeling in the dorsomedial, submedial, ventral medial and paratenial nuclei"' (p. 228). In the rabbit also, overlapping projections from the anteromedial, ventroanterior, and parataenial nuclei were found together with labeled neurons of the mediodorsal nucleus (Benjamin et al., 1978).

\section{BAND-LIKE ORGANIZATION OF THALAMOCORTICAL RELATIONS}

From their horseradish peroxidase studies in the monkey, Kievit and Kuypers $(1975,1977)$ came to the conclusion that "the thalamus seems to contain a hidden matrix of longitudinal cell columns which may represent the basic thalamic building blocks in respect to the specific thalamo-cortical connexions", (Kievit \& Kuypers, 1977, p. 317). Evidence for the same kind of organization has also been found in the cat's thalamus (Berson \& Graybiel, 1978).

As at least "some of the longitudinal groups of labelled neurons extended from one nucleus into another"' (Kievit \& Kuypers, 1977, p. 317), the precondition on which Rose and Woolsey (1948a) based their definition of the prefrontal cortex seems no longer valid.

\section{Possible Alternatives}

It now seems obvious that an exclusive reliance on 
mediodorsal afferents is no longer defensible in defining the prefrontal cortex of various mammalian species. The cortical regions to be included would be too divergent, including neo-, paleo-, and peripaleocortical fields (e.g., precentral, cingulate, and insular regions; cf. Stephan, 1975, for a definition of cortical terminology). One and the same field can be termed cingulate cortex or prefrontal cortex, depending on whether the anteromedial or the mediodorsal nucleus is viewed as the primary thalamic projection.

However, both cytoarchitecture and electrical unexcitability seem even less acceptable as bases for a definition of the prefrontal cortex of primates and nonprimates. And also a redefinition, based on a combination of all three criteria, including the mediodorsal nucleus, would discriminate in favor of primate species and against at least rodents and marsupials.

Accepting the view that-at least among speciesthere exists no area which unequivocally could be termed prefrontal cortex, we suggest a new approach to the definition of the prefrontal cortex. Its definition as the projection area of the mediodorsal nucleus may be adopted as a provisional starting point, independent of species. Based on this relationship, the prefrontal cortex of a given species may be determined further by investigating it as a whole and in parts, using a palette of different techniques. (Basically, a "part" may be any arbitrarily defined subarea; a part need not be defined cytoarchitectonically, though it could be.)

Anatomically, afferent and efferent projections of prefrontal subregions ("parts") may be compared and possible differences or communalities in cytoarchitecture and topologic and topographic organization may be investigated (e.g., Chavis \& Pandya, 1976; Jacobson \& Trojanowski, 1977). Behaviorally, animals with lesions of various prefrontal and associated areas (e.g., Divac, Markowitsch, \& Pritzel, 1978; Johnson, Rosvold, \& Mishkin, 1968) may be compared both by using traditional learning tasks and by studying them in more natural, species-specific situations (Warren, 1972). Neurochemical investigations (e.g., Björklund, Divac, \& Lindvall, 1978; Lindvall, Björklund, \& Divac, 1978), electrophysiological recordings (e.g., Markowitsch \& Pritzel, 1978), and the study of ontogenetic (e.g., Goldman, 1976; Johnson, Rosvold, Galkin, \& Goldman, 1976) and phylogenetic (e.g., Radinsky, 1975a, 1975b) relationships, may complement the bases for a redefinition of the prefrontal cortex.

Though this suggestion certainly appears ponderous and difficult to establish, it might be worthwhile. The outcomes of these diverse analyses would allow the student to compare and to select specific and common attributes of subregions between and within species. These comparisons then might lead to a determination of those areas which could be termed prefrontal cortex with certain graded probabilities.

Although this suggestion of combining the results obtained by different methods will not lead to the unequivocal establishment of the prefrontal cortex for a given species, it will nevertheless have the advantage that inferences about the so-called prefrontal areas are based not upon just one attribute (the projection of the mediodorsal nucleus), but upon a multitude of what now seem to be relevant attributes.

\section{REFERENCES}

Ariens-Kappers, C. U., Huber, G. C., \& Crosby, E. C. The comparative anatomy of the nervous system of vertebrates, including man (Vol. III). New York: Hafner, 1936.

AKERT, K. Comparative anatomy of frontal cortex and thalamofrontal connections. In J. M. Warren \& K. Akert (Eds.), The frontal granular cortex and behavior. New York: McGraw-Hill, 1964.

Avancini, G., Mancia, D., \& Pelliccioli, G. Ascending and descending connections of the insular cortex of the cat. Archives Italiennes de Biologie, 1969, 107, 696-714.

BECKSTEAD, R. M. Convergent thalamic and mesencephalic projections to the anterior medial cortex in the rat. Journal of Comparative Neurology, 1976, 166, 403-416.

Benevento, L. A., \& Loe, P. R. An intracellular study of thalamocortical synapses in the orbito-insular cortex of the cat. Experimental Neurology, 1975, 46, 634-643.

Benjamin, R. M., Jackson, J. C., \& Golden, G. T. Cortical projections of the thalamic mediodorsal nucleus in the rabbit. Brain Research, 1978, 141, 251-265.

Berson, D. M., \& Graybiel, A. M. Parallel thalamic zones in the LP-pulvinar complex of the cat identified by their afferent and efferent connections. Brain Research, 1978, 147, 139-148.

Bianchi, L. The functions of the frontal lobes. Brain, 1895, 18, 497-522.

BJöRKLUND, A., Divac, I., \& Lindvall, O. Regional distribution of catecholamines in monkey cerebral cortex, evidence for a dopaminergic innervation of the primate prefrontal cortex. Neuroscience Letters, 1978, 7, 115-119.

Bolton, J. S. The functions of the frontal lobes. Brain, 1903, 26, 215-241.

Brodmann, K. Vergleichende Lokalisationslehre der Grosshirnrinde in ihren Prinzipien dargestellt auf Grund des Zellenbaues. Leipzig, Germany: Barth, 1909.

BrodmanN, K. Neue Ergebnisse über die vergleichende histologische Lokalisation der Grosshirnrinde mit besonderer Berücksichtigung des Stirnhirns. Anatomischer Anzeiger, 1912, 41(Ergänzungsheft), 157-216.

BRUTKowsKI, S. Functions of prefrontal cortex in animals. Physiological Reviews, 1965, 45, 721-746.

Buser, P., \& Bignall, K. Nonprimary sensory projection on the neocortex. International Review of Neurobiology, 1967, 10, 111-165.

Chavis, D. A., \& Pandy A, D. N. Further observations on corticofrontal connections in the rhesus monkey. Brain Research, 1976, 117, 369-386.

Clark, W. E. LEG. An experimental study of thalamic connections in the rat. Philosophical Transactions of the Royal Society, Series B, 1932, 222, 1-28.

Clark, W. E. LeG., \& Boggon, R. H. On the connections of the medial cell groups of the thalamus. Brain, 1933, 56, 83-98.

Clark, W. E. LeG., \& Boggon, R. H. The thalamic connections of the parietal and frontal lobes of the brain in the monkey. Phil- 
osophical Transactions of the Royal Society, Series B, 1935, 224. 313-359.

Cow AN, W. M. Recent advances in neuroanatomical methodology. In D. B. Tower (Ed.), The nervous system (Vol. 1) The basic neurosciences. New York: Raven Press, 1975.

Crouch, R. L. The efferent fibres of the thalamus of Macaca rhesus. Journal of Comparative Neurology, 1940, 72, 177-186.

Divac, I., Kosmal, A., Buörkiund, A., \& Lindvall, O. Subcortical projections to the prefrontal cortex in the rat. Abstracts of the Society for Neuroscience, 1976, 2, 134.

Divac, I., Markowitsch, H. J., \& Pritzel, M. Behavioral and anatomical consequences of small intrastriatal injections of kainic acid in the rat. Brain Research, 1978, 151, 523-532.

Domesick, V. B. Thalamic relationships of the medial cortex in the rat. Brain, Behavior and Evolution, 1972, 6, 457-483.

FERRIER, D. The Croonian lecture. Experiments on the brain of monkeys (Second series). Philosophical Transactions of the Royal Society, 1875, 165, 433-488.

Feuchtw anger, E. Die Funktionen des Stirnhirns. Ihre Pathologie und Psychologie. Berlin: Springer, 1923.

Flechsig, P. Die Lokalisation der gestigen Vorgänge, insbesondere der Sinnesempfindungen des Menschen. Leipzig, Germany: Veit. 1896.

Franz, S. I. On the functions of the cerebrum: I. The frontal lobes in relation to the production and retention of simple sensory-motor habits. American Journal of Physiology, 1902, 8, $1-22$.

Freeman, W., \& Watts, J. W. Retrograde degeneration of the thalamus following prefrontal lobotomy. Journal of Comparative Neurology, 1947, 86, 65-93.

Goldman, P. S. Maturation of the mammalian nervous system and the ontogeny of behavior. Advances in the Study of Behavior, 1976, 7, 1.90.

Heimer, L.. \& Lohman, A. H. M. Anatomical methods for tracing connections in the central nervous system. In M. S. Gazzaniga \& C. Blakemore (Eds.), Handbook of psychobiology. New York: Academic Press, 1975.

Hines, M. On cerebral localization. Physiological Reviews, 1929, 9. 462-574.

Hitzig, E. Zur Physiologie des Grosshirns. Archiv für Psychiatrie und Nervenkrankheiten, 1884, 15, 270-275.

Horsley, V., \& SChÄFER, E. A. A record of experiments upon the functions of the cerebral cortex. Philosophical Transactions of the Royal Society. Series B, 1888, 179, 1-45.

Jacobson, S., \& Trojanowski, J. Q. Prefrontal granular cortex of the rhesus monkey. I. Intrahemispheric cortical afferents. Brain Research, 1977, 132, 209-233.

Johnson, T. N., Rosvold, H. E., Galkin, T. W., \& Goldman, P. S. Postnatal maturation of subcortical projections from the prefrontal cortex in the rhesus monkey. Journal of Comparative Neurology, 1976, 166, 427-444.

Johnson, T. N., Rosvold, H. E., \& Mishkin, M. Projections from behaviorally-defined sectors of the prefrontal cortex to the basal ganglia, septum, and diencephalon of the monkey. Experimental Neurology, 1968, 21, 20-34.

KiEvit, J., \& KuYpers, H. G. J. M. Subcortical afferents to the frontal lobe in the rhesus monkey studied by means of retrograde horseradish peroxidase transport. Brain Research, 1975, 85, 261-266.

Kievit, J., \& KuYPers, H. G. J. M. Organization of the thalamocortical connexions to the frontal lobe in the rhesus monkey. Experimental Brain Research, 1977, 29, 299-322.

Krettek, J. E., \& Price, J. L. The cortical projections of the mediodorsal nucleus and adjacent thalamic nuclei in the rat. Journal of Comparative Neurology, 1977, 171, 157-192.

KRIEG, W. J. S. Connections of the cerebral cortex. I. The albino rat. A. Topography of the cortical areas. Journal of Comparative Neurology, 1946, 84, 221-227.

KRIEG, W. J. S. Connections of the cerebral cortex. I. The albino rat. C. Extrinsic connections. Journal of Comparative Neurology. 1947, 86, 267-394.
Kristensson, K., \& Olson, Y. Retrograde axonal transport of protein. Brain Research, 1971, 29, 363-365.

LASEK, R., Joseph, B. S., \& Whitlock, D. G. Evaluation of a radioautographic neuroanatomical tracing method. Brain Research, 1968, 8, 319-336.

LASHLEY, K. S. Brain mechanisms and intelligence. Chicago: University of Chicago Press, 1929.

LASHLEY, K. S. Thalamo-cortical connections of the rat's brain. Journal of Comparative Neurology, 1941, 75, 67-122.

LAVAIL, J. H., \& LAVAIL, M. M. Retrograde axonal transport in the central nervous system. Science, 1972, 176, 1415-1417.

LeOnard, C. M. The prefrontal cortex of the rat. I. Cortical projection of the mediodorsal nucleus. II. Efferent connections. Brain Research, 1969, 12, 321-343.

Leonard, C. M. The connections of the dorsomedial nuclei. Brain, Behavior and Evolution, 1972, 6, 524-541.

Lindvall, O., Buörklund, A., \& Divac, I. Organization of catecholamine neurons projecting to the frontal cortex in the rat. Brain Research, 1978, 142, 1-24.

Locke, S. Thalamic connections to insular and opercular cortex of monkey. Journal of Comparative Neurology, 1967, 129, 219-240.

LUKASZEWSKA, I. Perseverative errors in normal and frontal rats in returning behavior test. Acta Neurobiologiae Experimentalis, 1971, 31, 101-109.

Markowitsch, H. J., \& Pritzel, M. Learning and the prefrontal cortex of the cat: Anatomico-behavioral interrelations. Physiological Psychology, 1976, 4, 247-261.

Markowitsch, H. J., \& Pritzel, M. Comparative analysis of prefrontal learning functions in rats, cats, and monkeys. Psychological Bulletin, 1977, 84, 817-837.

Markowitsch, H. J., \& Pritzel, M. Single unit activity in cat prefrontal and posterior association cortex during performance of spatial reversal tasks. Brain Research, 1978, 149, 53-76.

Markowitsch, H. J., Pritzel, M., \& Divac, I. The prefrontal cortex of the cat: Anatomical subdivisions based on retrograde labeling of cells in the mediodorsal thalamic nucleus. Experimental Brain Research, 1978, 32, 335-344.

Mesulam, M.-M., van Hoesen, G. W., Pandya, D. N., \& GESCHWIND. N. Limbic and sensory connections of the interior parietal lobule (area PG) in the rhesus monkey: A study with a new method for horesradish peroxidase histochemistry. Brain Research, 1977, 136, 393-414.

MetTLER, F. A. Extracortical connections of the primate cerebral cortex. Journal of Comparative Neurology, 1947, 86, 95-117.

Meyer, A., Beck, E., \& McLardy, T. Prefrontal leucotomy: A neuro-anatomical report. Brain, 1947, 70, 18-49.

MinkowsKi, M. Étude sur les connexions anatomiques des circonvolutions rolandiques, pariétales et frontales. Schweizer Archiv fur Neurologie, Neurochirurgie und Psychiatrie, 1923, 12, 71-104.

MonaKow, C. von. Experimentelle und pathologisch-anatomische Untersuchungen über die Haubenregion, den Sehhügel und die Regio subthalamica, nebst Beiträgen zur Kenntnis früh erworbener Gross- und Kleinhirndefekte. Archiv für Psychiatrie und Nervenkrankheiten, 1895, 27, 1-128 and 386-479.

Mountcastle, V. B., \& Poggio, G. F. Structural organization and general physiology of thalamotelencephalic systems. In V. B. Mountcastle (Ed.), Medical physiology (Vol. 1). St. Louis: C. V. Mosby, 1974.

NARKIEwICZ, O., \& BRUTKowsKI, S. The organization of projection from the thalamic mediodorsal nucleus to the prefrontal cortex of the dog. Journal of Comparative Neurology, 1967 , 129, 361-374.

Niımi, K., NiImi, M., \& OKada, Y. Thalamic afferents to the limbic cortex in the cat studied with the method of retrograde axonal transport of horseradish peroxidase. Brain Research, 1978, 145, 225-238.

Passingham, R. The function of prefrontal cortex in the tree shrew (Tupaia belangeri). Brain Research, 1978, 145, 147-152.

Pribram, K. H., Chow, K. L.. \& Semmes, J. Limit and organiza- 
tion of the cortical projection from the medial thalamic nucleus in the monkey. Journal of Comparative Neurology, 1953, 98, 433-446.

RADINSKy, L. Evolution of the felid brain. Brain, Behavior and Evolution, 1975, 11, 214-254. (a)

Radinsky, L. Primate brain evolution. American Scientist, 1975, 63, 656-663. (b)

Rose. J. E., \& Woolsey. C. N. The orbitofrontal cortex and its connections wit": the mediodorsal nucleus in rabbit, sheep, and cat. In J. F. Fulton, C. D. Aring, \& S. B. Wortis (Eds.), Research publications for research in nervous and mental disease: The frontal lobes (Vol. 27). Baltimore, Md: Williams \& Wilkins, 1948. (a)

Rose, J. E., \& Woolsey, C. N. Structure and relations of limbic cortex and anterior thalamic nuclei in rabbit and cat. Journal of Comparative Neurology, 1948, 89, 279-347. (b)

Rose, J. E., \& Woolsey, C. N. Organization of the mammalian thalamus and its relationships to the cerebral cortex. Electroencephalography and Clinical Neurophysiology, 1949, 1, 391-404.

Rose, M. Cytoarchitektonischer Atlas der Grosshirnrinde der Maus. Journal fur Psychologie und Neurologie, 1929, 40, 1-51.

RUTISHAUSER, F. Experimenteller Beitrag zur Stabkranzfaserung im Frontalhirn des Affen. Monatsschrift fur Psychiatrie und Neurologie, 1899, 5, 161-180.

SACHS, E. On the structure and functional relations of the optic thalamus. Brain, 1909, 32, 7-186.

SHIPLEY, J. E., \& KolB, B. Neural correlates of species-typical behavior in the Syrian golden hamster. Journal of Comparative and Physiological Psychology, 1977, 91, 1056-1073.

SKeEN, L. C. The organization of the medial dorsal nucleus in the tree shrew (Tupaia glis). Anatomical Record, 1974, 178, 465.

Skeen, L. C., \& Masterton, R. B. Origins of anthropoid intelligence. III. Role of prefrontal system in delayed-alternation and spatial-reversal learning in a prosimian (Galago senegalensis). Brüin, Behavior and Evolution, 1976, 13, 179-195.

STANLEY, W. C., \& JAYNES, J. The function of the frontal cortex. Psychological Review, 1949, 56, 18-32.

Stanton, G. B., Cruce, W. L. R., Goldberg, M. E., \& Robinson, D. L. Corticocortical and corticothalamic projections to area 7 of monkey cerebral cortex. Anatomical Record, 1977, 187, 722. (a)
Stanton, G. B., Cruce, W. L. R., Goldberg, M. E. \& Robinson, D. L. Some ipsilateral projections to areas PF and PG of the inferior parietal lobule in monkeys. Neuroscience Letters, 1977, 6, 243-250. (b)

Stephan, H. Allocortex. Handbuch der mikroskopischen Anatomie des Menschen (Vol. IV/9). Berlin: Springer, 1975.

TовіAs, T. J. Afferents to prefrontal cortex from the thalamic mediodorsal nucleus in the rhesus monkey. Brain Research, 1975, 83, 191-212.

Tobias, T. J.. \& EBNer, F. F. Thalamocortical projections from: the mediodorsal nucleus in the Virginia opossum. Brain Research, 1973, 52, 79-96.

Trojanowski, J. Q. Pulvinar and other caudal thalamic afferents to superior temporal gyrus in the rhesus monkey. Abstracts of the Society for Neuroscience, 1977, 3, No. 215.

TROJANOWSKI, J. Q., \& JACOBSON, S. Areal and laminar distribution of some pulvinar cortical efferents in rhesus monkey. Journal of Comparative Neurology, 1976, 169, 371-392.

W ALKer, A. E. The medial thalamic nucleus. A comparative anatomical, physiological and clinical study of the nucleus medialis dorsalis thalami. Journal of Comparative Neurology, 1940, 73, 87-115.

WALKER, A. E. The development of the concept of cerebral localization in the nineteenth century. Bulletin of the History of Medicine, 1957, 31, 99-121.

WALlER, W. H. Thalamic connections of the frontal cortex of the cat. Journal of Comparative Neurology, 1940, 73, 117-138.

W ALLER, W. H., \& BARRIS, R. W. Relationships of thalamic nuclei to the cerebral cortex in the cat. Journal of Comparative Neurology, 1937, 67, 317-341.

W ARREN, J. M. Evolution, behavior and the prefrontal cortex. Acta Neurobiologiae Experimentalis, 1972, 32, 581-593.

W ARREN, J. M., \& AKERT, K. (Eds.), The frontal granular cortex and behavior. New York: McGraw-Hill, 1964.

W ARREN, J. M., W ARRen, H. B., \& AKert, K. Orbitofrontal cortical lesions and learning in cats. Journal of Comparative Neurology, 1962, 118, 17-41.

Wundt, W. Grundzüge der physiologischen Psychologie (Vol. 1). Leipzig, Germany: W. Engelmann, 1908.

(Received for publication May 12, 1978; revision accepted September 8, 1978.) 